\title{
Eksplorasi Pemahaman Konsep Siswa pada Fluida Statis Berdasarkan Authentic Learning Berbasis Fenomena
}

\author{
Mohammad Zaky Tatsar ${ }^{1}$, Lia Yuliati ${ }^{1}$, Hari Wisodo ${ }^{1}$ \\ ${ }^{1}$ Pendidikan Fisika-Universitas Negeri Malang
}

\section{INFO ARTIKEL}

\section{Riwayat Artikel:}

Diterima: 28-06-2019

Disetujui: 24-01-2020

Kata kunci:
concept understanding;
static fluid;
authentic learning;
pemahaman konsep;
fluida statis;
authentic learning

Alamat Korespondensi:

Mohammad Zaky Tatsar

Pendidikan Fisika

Universitas Negeri Malang

Jalan Semarang 5 Malang

E-mail: zakytatsar1000@gmail.com

\begin{abstract}
ABSTRAK
Abstract: This study aims to explore the understanding of students' concepts based on the experience of authentic phenomenom-based learning in static fluid material. The method in this study using a mix method approach with embedded experimental model research design. The data were obtained based on the isomorphic multiple choice test and interview support. Through data analysis, the results of the calculation of N-Gain values were obtained which showed there was an increase in students' understanding of concepts in the medium category and the effect size in the low category. Qualitatively, after experiencing authentic learning based on the phenomenon of understanding concepts students experience changes that lead to understanding the correct concepts in each isomorphic.
\end{abstract}

\begin{abstract}
Abstrak: Penelitian ini bertujuan untuk mengeksplorasi pemahaman konsep siswa berdasarkan pengalaman authentic learning berbasis fenomena pada materi fluida statis. Metode dalam penelitian ini menggunakan pendekatan mix method dengan desain penelitian embedded experimental model. Data diperoleh berdasarkan tes pilihan ganda berbentuk isomorfik dan dukungan wawancara. Melalui analisis data, diperoleh hasil perhitungan nilai $\mathrm{N}$-Gain yang menunjukkan terdapat peningkatan pemahaman konsep siswa pada kategori sedang serta effect size pada kategori rendah. Secara kualitatif, setelah mengalami authentic learning berbasis fenomena pemahaman konsep, siswa mengalami perubahan menuju pemahaman konsep yang benar pada setiap isomorfik.
\end{abstract}

Fluida statis termasuk bagian dari materi fisika yang dipelajari di tingkat SMA. Fluida statis dipelajari pada kelas XI yang merupakan bagian dari materi dasar yang harus dikuasi oleh siswa yang mencakup teori atau kompetensi inti III dan praktik yang merupakan kompetensi inti IV. Secara khusus, pembelajaran dalam fluida statis terdiri dari konsep tekanan dan hukum Archimedes (Serway \& Vuille, 2014). Selain itu, fluida statis menjadi dasar untuk beberapa sub materi lain dalam fisika, terutama fluida dinamis (Young \& Meredith, 2017). Beberapa penelitian menunjukkan terdapat kesulitan yang dialami siswa dalam materi fluida statis. Sebagian besar siswa beranggapan banyaknya fluida di atas benda sebanding dengan tekanan hidrostatis yang dialami oleh benda (Berek, Sutopo, \& Munzil, 2016; Goszewski et al., 2013; Loverude, Heron, \& Kautz, 2010; Wijaya, Supriyono Koes, \& Muhardjito, 2016), semakin tinggi benda dalam fluida gaya angkat benda juga semakin besar (Heron et al., 2003; Wagner, Carbone, \& Lindow, 2013). Selain itu, masih terdapat miskonsepsi tentang Hukum gas ideal (Kautz et al., 2013), dan volume gas ideal (Robertson et al., 2016).

Kesulitan memahami materi fluida statis bagi siswa menunjukkan masih banyaknya miskonsepsi pada siswa. Miskonsepsi yang dimiliki siswa secara tidak langsung akan menghambat siswa dalam membangun pengetahuan baru (Tama 's Tura 'nyi, 2013). Selain itu, dibutuhkan waktu lama dalam mengubah miskonsepsi (Sencar \& Eryilmaz, 2004; Hung \& Jonassen, 2006; Stylos, Evangelakis, \& Kotsis, 2008; Docktor \& Mestre, 2014; Widowati, Nurohman, \& Anjarsari, 2017). Disisi lain banyaknya kesulitan siswa menunjukkan rendahnya pemahaman konsep siswa. Pemahaman konsep merupakan faktor utama yang ditekankan dalam pembelajaran, lebih lebih dalam pembelajaran fisika (Hill, Sharma, \& Johnston, 2015). Pemahaman konsep siswa yang benar memudahkan siswa menganalisis fenomena dengan cara melakukan pemecahan masalah dengan baik (Harskamp \& Ding, 2006; Sabella \& Redish, 2007). Siswa yang pemahaman konsepnya bagus akan mampu mengidentifikasi serta menyelesaikan beberapa permasalahan fenomena-fenomena sekitar dengan benar (Serway \& Vuille, 2014). Selain itu, apabila siswa memiliki pemahaman konsep yang baik, maka pembelajaran akan sukses dalam membantu siswa meminimalisir miskonsepsi (Eraikhuemen et ., 2014; Ergin, 2016). 
Beberapa faktor penyebab rendahnya pemahaman konsep siswa adalah siswa mengalami kesalahan dalam membentuk konsepsi ketika pembelajaran fisika (Halim, Yong, Subahan, \& Meerah, 2014), atau sebelum mempelajari konsep yang baru mereka belum memiliki konsep dasar atau konsep sebelumnya (Tama's Tura 'nyi, 2013). Selain itu, pemberian konsep yang tidak sesuai oleh pendidik (Yalcin et al., 2009; Docktor \& Mestre, 2014). Adapun faktor lain yang menyebabkan rendahnya kemampuan pemecahan masalah siswa adalah proses pembelajaran yang tidak sesuai berdasarkan karakteristik materi fluida statis. Siswa dapat menggali dan membangun konsep-konsep secara bermakna dengan melibatkan masalah nyata. Selain itu, siswa mengetahui fenomena-fenomena pada materi fluida statis. Pembelajaran sains di sekolah dapat diterapkan dengan menghubungkan materi dalam pembelajaran dengan kehidupan nyata (Fitriani et al., 2016).

Salah satu bentuk pembelajaran yang sesuai untuk diterapkan adalah authentic learning. Authentic learning memungkinkan siswa menggali, mendiskusikan, dan membangun konsep-konsep dan hubungan-hubungan secara bermakna dengan melibatkan masalah nyata yang relevan terhadap siswa (Lombardi, 2007). Authentic learning memiliki beberapa karakteristik yang sesuai dengan pembelajaran fluida statis, di antaranya membangun konsep-konsep dan hubungan-hubungan secara bermakna melalui permasalahan nyata yang relevan (Lombardi \& Oblinger, 2007; Howland et al., 2012) memberikan kesempatan bagi siswa untuk mengeksplorasi dan membangun konsep (Donovan \& Pellegrino, 2014), serta pendekatan pedagogis untuk melibatkan siswa untuk menyelesaikan terkait permasalahan nyata (Lam, 2013).

Penggunaan pembelajaran berbasis fenomena memberikan beberapa dampak positif dalam pembelajaran fisika. Pembelajaran berbasis fenomena menciptakan lingkungan belajar yang mendorong peserta didik mengonstruk pengetahuan dan keterampilan berdasarkan pengalaman langsung (Kaniawati et al., 2010). Selain itu, dalam pembelajaran diharapkan siswa mengetahui hubungan materi yang mereka pelajari dengan fenomena yang terjadi dalam kehidupan nyata (Mims, 2003). Dekade terakhir ini penelitian pemahaman konsep pada bidang fisika telah mengalami perkembangan melalui beberapa penelitian. Penelitian terkait pemahaman konsep dan kemampuan pemecahan masalah diantaranya oleh (Čančula, Planinšič, \& Etkina, 2015; Docktor et al., 2015; Buteler \& Coleoni, 2016; Nurita, Hastuti, \& Sari, 2017; Widowati et al., 2017; Riantoni et al., 2017). Selain itu, beberapa penelitian terkait dengan authentic learning dan pembelajaran berbasis fenomena telah banyak dilakukan dalam bidang pendidikan. Penelitian terkait authentic learning telah dilakukan oleh (Moodley, 2001; Anwari et al., 2015; Sambeka \& Sriyati, 2017; Muganga, 2015; Rochmawati \& Wahyuni, 2017). Adapun penelitian pembelajaran berbasis fenomena telah dilakukan oleh (Brookes \& Etkina, 2010; Teiermayer, 2016; Hadzibegovic \& Klokic, 2016; Kaur, 2017; Leiti $i 1 / 20$ et al., 2017). Namun, penelitian pada pemahaman konsep melalui authentic learning berbasis fenomena yang telah dipublikasi masih sulit ditemukan.

\section{METODE}

Penelitian dilakukan melalui pendekatan mixed methods desain embedded experimental model. Penelitian ini dilaksanakan pada bulan Februari 2019 terhadap 32 siswa kelas XI MIA MA Almaarif Singosari Tahun Pelajaran 2018/2019. Model pembelajaran yang diterapkan adalah authentic learning berbasis fenomena, yang terdiri dari empat fase pembelajaran yaitu Phase 1: engagement pada fase ini terdiri dari Setting and Scenario, real-world relevance dan defined problem, Phase 2: inquiry pada fase ini terdiri dari collaboration dan sustained investigation, Phase 3: the learning process pada fase ini terdiri dari interdisciplinary perspective dan multiple sources and perspectives, dan Phase 4: communication pada fase ini terdiri dari reflection dan multiple interpretations and outcomes. Adapun data yang dikumpulkan adalah hasil jawaban siswa dalam menyelesaikan soal pada konsep fluida statis. Teknik pengambilan data berupa pretest dan posttest soal pemahaman konsep berupa tes pilihan ganda berbentuk isomorfik. Data hasil jawaban siswa tersebut dianalisis berdasarkan kategori yang telah dibuat oleh peneliti dalam FIDTI (Fluid Isomorpfic Diagnostic Test Inventory). Jawaban siswa yang telah dianalisis kemudian dikonfirmasi dengan data hasil wawancara, dan disajikan dalam bentuk naratif dan tabel. Dari semua data hasil tes dan wawancara kemudian diinterpretasi hasilnya untuk ditarik kesimpulan.

\section{HASIL}

\section{Deskripsi Statistik Peningkatan Pemahaman Konsep Siswa}

Analisis kemampuan pemecahan konsep siswa diawali dengan analisis deskriptif dengan tujuan untuk mendeskripsikan pemahaman konsep siswa sebelum dan sesudah pembelajaran Authentic Learning berbasis fenomena. Hasil peningkatan kemampuan pemecahan masalah siswa dinyatakan dengan nilai rata-rata N-Gain. Hasil analisis statistik pemahaman konsep ditunjukan pada tabel 1 .

Tabel 1. Analisis Statistik Pemahaman Konsep

\begin{tabular}{cc}
\hline Statistik & Posttest \\
\hline $\mathrm{N}$ & 32 \\
Nilai Maksimum & 15,00 \\
Nilai Minimum & 7,00 \\
Standar Deviasi & 1,855 \\
Mean & 10,09 \\
\hline
\end{tabular}


Setelah dilakukan analisis statistik deskriptif, sebelum melakukan uji beda menggunakan paired t-Test, dilakukan uji normalitas sebagai uji prasyarat analisis statistik parametrik. Berdasarkan hasil uji normalitas data posttest diperoleh hasil bahwa terdapat data yang tidak terdistribusi normal, hal tersebut terlihat pada nilai signifikasi data posttest yaitu pada uji normalitas Kolmogorov-Sminorv sebesar 0,000 yang lebih kecil dari taraf signifikan 0,05. Hasil uji normalitas secara lengkap disajikan pada tabel 2.

Tabel 2. Hasil Uji Normalitas Pemahaman Konsep

\begin{tabular}{ccccc}
\hline \multirow{2}{*}{ Data } & \multicolumn{3}{c}{ Kolmogorov-Sminorv } & \multirow{2}{*}{ Keterangan } \\
\cline { 2 - 4 } & Statistic & df & Sig. & \\
\hline Posttest & 0,222 & 32 & 0,000 & Tidak normal \\
\hline
\end{tabular}

Setelah diketahui data terdistribusi tidak normal maka peningkatan kemampuan pemecahan masalah dilanjutkan dengan uji $\mathrm{N}$-Gain, Efffect Size, dan uji statistik nonparametrik Wilcoxon. Berdasarkan hasil perhitungan yang diperoleh, kemampuan pemecahan masalah siswa yang mengalami pembelajaran authentic learning berbasis fenomena mengalami peningkatan dalam kategori sedang yaitu sebesar 0,52. Kekuatan pembelajaran authentic learning berbasis fenomena terhadap kemampuan pemecahan masalah siswa termasuk dalam kategori rendah dengan nilai effect size 0,41. Uji beda Wilcoxon diperoleh nilai uji beda sebesar 4,645 dengan nilai asymp sig (2-tailed) sebesar 0,000 yang menunjukkan terdapat perbedaan yang signifikan antara sebelum dan sesudah mengalami authentic learning berbasis fenomena. Secara lengkap sebagaimana pada tabel 3 .

Tabel 3. Uji Statistik Pemahaman Konsep Siswa

\begin{tabular}{ccc}
\hline Statistik & Nilai & Keterangan \\
\hline Nilai Z & 4,645 & Perubahan skor pemahaman konsep signifikan \\
Asymp. Sig (2-tailed) & 0,000 & Sedang \\
Nilai N-Gain & 0,52 & Sedang \\
Effect Size) & 0,41 & \\
\hline
\end{tabular}

\section{Deskripsi Peningkatan Kemampuan Pemecahan Masalah Siswa}

Data pemahaman konsep siswa pada materi fluida statis yang mengalami authentic learning berbasis fenomena secara keseluruhan disajikan sebagaimana gambar 1.

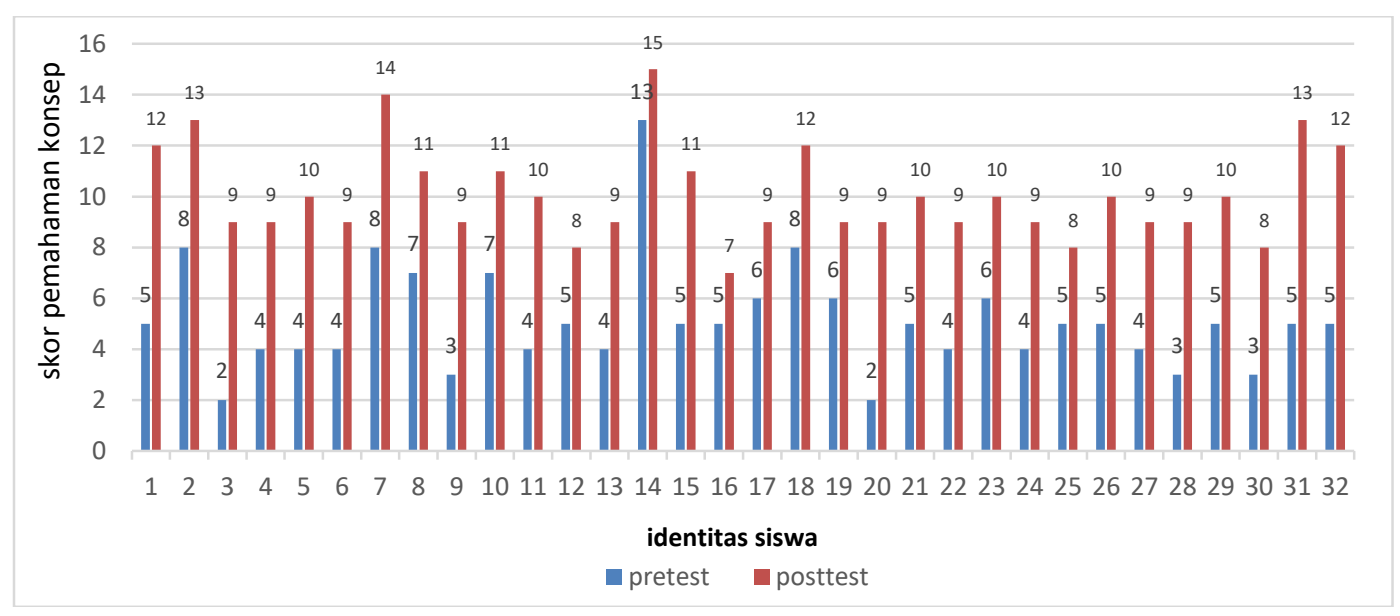

\section{Gambar 1. Sebaran Skor Pemahaman Konsep Siswa}

Berdasarkan gambar 1 dapat diketahui bahwa masing-masing siswa mengalami peningkatan skor pemahaman konsep berdasarkan pengalaman authentic learning berbasis fenomena. Beberapa siswa mengalami peningkatan pemahaman konsep yang signifikan, sebagaimana terlihat pada siswa no urut 31 dengan peningkatan 8 poin, serta siswa no urut 1,3 , dan 32 yang masing-masing mengalami kenaikan nilai pretest dan posttest sebesar 7 poin. Peningkatan tersebut lebih dari $45 \%$ dari nilai maksimal 15 poin dan rata-rata peningkatan nilai pemahaman konsep sebesar 5 poin. 


\section{Deskripsi Pemahaman Konsep Siswa Berdasarkan Kategori Pemahaman Konsep}

Kategori pemahaman konsep terdiri dari 4 kategori untuk masing-masing isomorfik. Siswa dikatakan memiliki kategori tersebut ketika menjawab minimal 2 dari 3 soal pada masing-masing isomorfik. Konsepsi kategori 1, 2, dan 3 merupakan bentuk miskonsepsi, sedangkan konsepsi kategori 4 merupakan konsepsi yang benar. Pemahaman konsep siswa berdasarkan kategori pemahaman konsep secara rinci disajikan sebagaimana gambar 2.

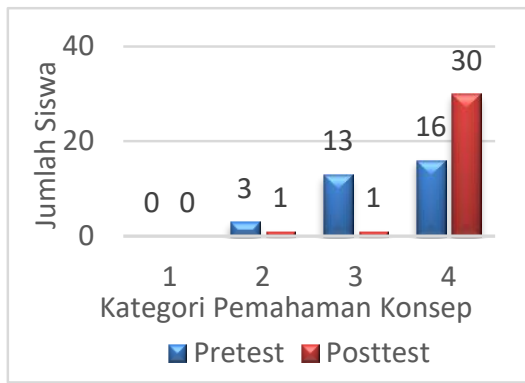

(a)

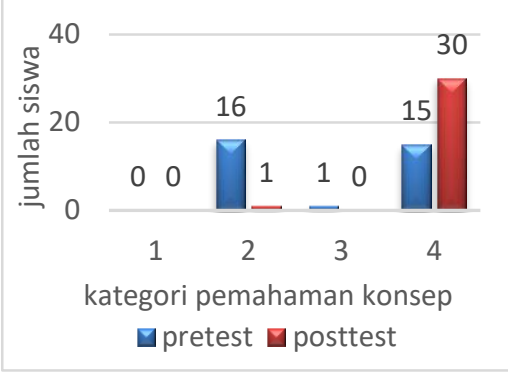

(b)

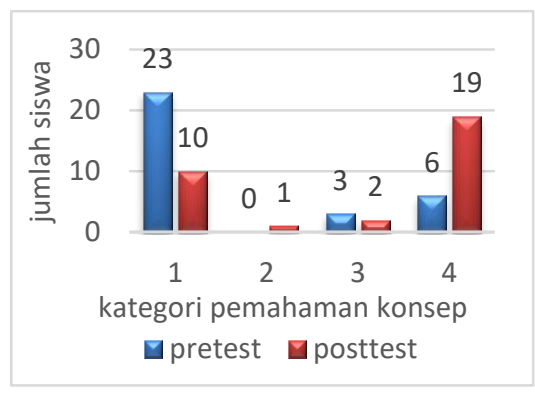

(e)

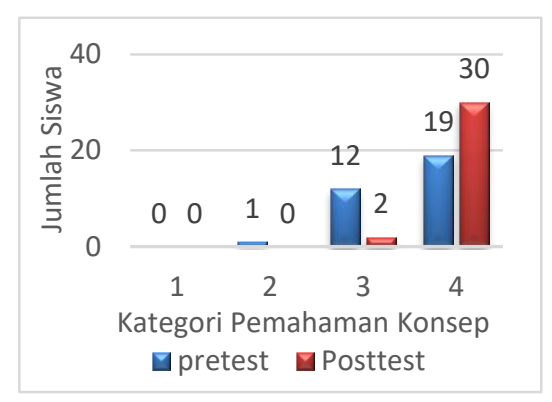

(c)

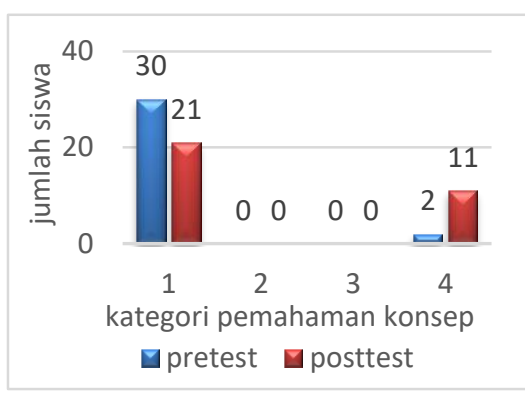

(d)

Gambar 2 (a) Pemahaman Konsep Siswa pada Isomorfik 1 (b), Isomorfik 2, (c) Isomorfik 3 (d) Isomorfik 4, (e) Isomorfik 5

Pemahaman konsep siswa secara keseluruhan pada isomorfik tentang tekanan hidrostatis disajikan sebagaimana Gambar 2 (a). Berdasarkan gambar 2 (a) secara keseluruhan setelah mengalami authentic learning berbasis fenomena, konsepsi siswa mengalami perubahan dari konsepsi kategori 2 (Siswa memiliki konsepsi bahwa tekanan hidrostatis bergantung pada kedalaman benda/titik diukur dari dasar bejana) dan kategori 3 (siswa memiliki konsepsi bahwa tekanan hidrostatis bergantung pada massa benda dan kedalaman benda/titik diukur dari permukaan fluida) menjadi konsepsi kategori 4 (siswa mampu menentukan tekanan hidrostatis benda dalam fluida secara tepat. Tekanan hidrostatis bergantung pada tekanan yang bekerja pada permukaan fluida, massa jenis fluida, percepatan gravitasi, dan kedalaman benda/titik diukur dari permukaan fluida).

Secara keseluruhan pemahaman konsep siswa pada isomorfik tentang hukum utama hidrostatis yaitu sebagaimana gambar 2 (b). Berdasarkan Gambar 2 (b) secara keseluruhan, konsepsi siswa mengalami perubahan dari konsepsi kategori 2 (siswa memiliki konsepsi bahwa tekanan hidrostatis yang dialami benda/titik bergantung pada banyaknya zat cair di dalam bejana) dan kategori 3 (siswa memiliki konsepsi bahwa tekanan hidrostatis yang dialami benda/titik bergantung pada luas penampang permukaan bejana) menjadi konsepsi kategori 4 (Siswa mampu menentukan tekanan hidrostatis benda dalam suatu fluida secara tepat. Tekanan hidrostatis bergantung pada tekanan yang bekerja pada permukaan fluida, massa jenis fluida, percepatan gravitasi, dan kedalaman benda/titik diukur dari permukaan fluida), dimana sebagian besar terpusat pada konsepsi kategori 4.

Pemahaman konsep siswa secara keseluruhan pada Isomorfik tentang aplikasi hukum utama hidrostatis berdasarkan pengalaman authentic learning berbasis fenomena adalah sebagaimana gambar 2 (c). Berdasarkan Gambar 2 (c) secara keseluruhan setelah mengalami authentic learning berbasis fenomena, konsepsi siswa mengalami perubahan dari konsepsi kategori 2 (siswa memiliki konsepsi bahwa tekanan hidrostatis hanya bergantung pada banyaknya fluida dalam bejana) dan kategori 3 (Siswa memiliki konsepsi bahwa tekanan hidrostatis bergantung pada massa benda dan kedalaman benda/titik diukur dari permukaan fluida) menjadi konsepsi kategori 4 (siswa memiliki konsepsi bahwa tekanan hidrostatis bergantung pada tekanan atmosfer, massa jenis fluida, percepatan gravitasi, dan kedalaman benda/titik diukur dari permukaan fluida), dimana sebagian besar terpusat pada konsepsi kategori 4.

Pemahaman konsep siswa secara keseluruhan pada Isomorfik tentang Hukum archimedes adalah sebagaimana Gambar 2 (d). Berdasarkan gambar 2, (d) secara keseluruhan setelah mengalami authentic learning berbasis fenomena, konsepsi siswa mengalami perubahan dari konsepsi kategori 1 (Siswa memiliki konsepsi bahwa besar gaya angkat fluida relatif terhadap dasar bejana) menjadi konsepsi kategori 4 (siswa mampu menentukan besar gaya angkat benda dalam suatu fluida secara tepat. Besar 
gaya angkat fluida pada benda dalam keadaan terapung dan melayang sama besar dengan berat benda $\left(\mathrm{F}_{\mathrm{A}}=\mathrm{W}\right)$. Besar gaya angkat fluida pada benda yang tenggelam lebih kecil dari berat benda $\left(\mathrm{F}_{\mathrm{A}}<\mathrm{W}\right)$ dikarenakan terdapat gaya normal oleh dasar bejana), walaupun sebagian besar terpusat pada konsepsi kategori 4.

Isomorfik 5 terdiri dari soal nomor 5, 10, dan 15 pada soal conceptual understanding. Indikator pada isomorfik 5 adalah menganalisis penerapan Hukum pascal dalam kehidupan sehari-hari. Pemahaman konsep siswa secara keseluruhan pada isomorfik 5 adalah sebagaimana Gambar 2 (e). Berdasarkan Gambar 2 (e) secara keseluruhan setelah mengalami authentic learning berbasis fenomena, konsepsi siswa mengalami perubahan dari konsepsi kategori 1 (siswa memiliki konsepsi bahwa besar gaya tekan yang dibutuhkan untuk menyeimbangkan beban pada bejana berhubungan sebanding dengan banyaknya luasan yang digunakan) dan kategori 3 (Siswa memiliki konsepsi bahwa besar gaya tekan yang dibutuhkan untuk menyeimbangkan beban pada bejana berhubungan dibagi berdasarkan banyaknya penampang (semakin banyak maka gaya yang dibutuhkan tersebar merata pada masing-masing penampang)) menjadi konsepsi kategori 4 (Siswa mampu menentukan besar gaya tekan yang dibutuhkan untuk menyeimbangkan beban pada bejana berhubungan secara tepat. Besar gaya tekan sesuai dengan hukum Pascal yaitu $F_{1} / A_{1}=F_{2} / A_{2}=F_{n} / A_{n}$ ), dari konsepsi kategori 1 menuju konsepsi kategori 2 dimana sebagian besar terpusat pada konsepsi kategori 4.

\section{PEMBAHASAN}

Dalam penelitian ini, pemahaman konsep siswa diukur menggunakan empat kategori konsepsi pada tiap tiap isomorfik, Pada saat posttest pada masing-masing isomorfik, pemahaman konsep siswa berubah ke arah yang lebih baik. Hal tersebut terlihat dari berkurangnya konsepsi siswa pada kategori miskonsepsi (kategori 1, 2, dan 3) serta bertambahnya konsepsi siswa pada kategori konsep yang benar (kategori 4) pada setiap isomorfik. Namun pada isomorfik 4 walaupun mengalami peningkatan pada konsepsi benar, secara keseluruhan siswa lebih banyak yang mengalami miskonsepsi. Sehingga pada isomorfik 4 yang merupakan sub materi Hukum archimedes, sebagaian besar siswa masih mengalami miskonsepi. Begitu juga (Heron et al., 2003; Wagner et al., 2013; Wagner, Cohen, \& Moyer, 2009) menunjukkan banyaknya miskonsepsi yang dialami oleh siswa. Banyaknya siswa yang mengalami miskonsepsi tersebut berdasarkan hasil wawancara, siswa kurang memahami fenomena dalam permasalahan yang diberikan. Berdasarkan hasil wawancara kepada siswa yang memiliki pemahaman konsep yang tinggi mengungkapkan strategi yang digunakan yaitu cenderung memulai dengan mendeskripsikan informasi secara kualitatif terlebih dahulu dengan memahami permasalahan yang diberikan, dan menggunakan informasi tersebut untuk menghubungkan dengan konsep yang sesuai. Siswa juga menggunakan lebih banyak representasi dan menghubungkan konsep-konsep yang berguna dalam menghadapi fenomena atau permasalahan yang diberikan. Hasil penelitian ini sesuai dengan hasil penelitian sebelumnya bahwasannya penggunaan representasi yang berbeda termasuk fenomena dapat meningkatkan pemahaman konsep siswa (Hubber, Tytler, \& Haslam, 2010; Prain, Tytler, \& Peterson, 2009).

Pemahaman konsep siswa secara keseluruhan setelah mengalami authentic learning berbasis fenomena mengalami perubahan yang positif. Hal ini menunjukkan bahwa terjadi peningkatan pada pemahaman konsep siswa setelah diajar menggunakan authentic learning berbasis fenomena. Peningkatan tersebut juga terlihat dari nilai $N$-Gain dan juga melalui skor effect size dalam hal pengaruhnya. meningkatnya pemahaman konsep siswa tidak terlepas dari proses pembelajaran yang berorientasi pada fenomena nyata untuk memperkuat pemahaman konsep siswa. Pembelajaran yang berorientasi pada fenomena nyata menjadi salah motivasi kebanyakan siswa yang membuat mereka lebih aktif dalam pembelajaran (Callison, \& Lamb, 2004; Maina, 2015). Hal ini disebabkan siswa merasa tertarik terhadap fenomena yang diberikan, serta siswa memiliki keinginan untuk dapat menjelaskan fenomena yang diberikan dari segi sains (Kolb, 2015). Melalui authentic learning berbasis fenomena siswa terlibat dalam masalah penyelidikan dunia nyata yang melibatkan keterampilan berpikir tingkat tinggi. Hal ini sesuai dengan (Rule, 2006) bahwa lingkungan belajar otentik yang melibatkan siswa dalam masalah penyelidikan dunia nyata yang melibatkan keterampilan berpikir tingkat tinggi serta praktikum dapat memberikan peluang penting untuk berinteraksi dengan komunitas yang lebih luas dan refleksi atas pengalaman sehingga memperkuat pemahaman baru. Selain itu memberikan siswa kesempatan untuk memeriksa masalah dari berbagai sudut pandang, yang memungkinkan adanya solusi yang beragam yang dapat menambah pemahaman siswa (Herrington \& Herrington, 2005; Lombardi, 2007; Mims, 2003; Rule, 2006).

\section{SIMPULAN}

Pemahaman konsep siswa mengalami perubahan positif berdasarkan authentic learning berbasis fenomena. Selain itu melalui authentic learning berbasis fenomena siswa mengalami peningkatan kategori konsepsi dengan menurunnya persentase siswa pada kategori miskonsepsi (kategori 1,2, dan 3) serta bertambahnya konsepsi siswa pada kategori konsep yang benar (kategori 4) pada setiap isomorfik. Sehingga authentic learning berbasis fenomena terbukti cukup efektif dalam meningkatkan pemahaman konsep siswa. Berkaitan dengan hal tersebut, diharapkan kepada para pendidik dapat menerapkan authentic learning berbasis fenomena pada materi fisika lainnya sehingga dapat meminimalisir miskonsepsi pada siswa. Perubahan positif juga terlihat dari lebih besarnya nilai sesudah dibandingkan nilai sebelum mengalami authentic learning berbasis fenomena.

Peningkatan tersebut juga terlihat dari nilai N-Gain sebesar 0,52 (kategori sedang) serta nilai effect size sebesar 0,42 (kategori rendah). Di sisi lain, pembelajaran yang mampu mengaitkan dengan fenomena kehidupan sehari-hari dapat menarik minat siswa ketika belajar fisika. Selain itu, pemberian fenomena baik secara kuantitas maupun keotentikannya perlu ditekankan untuk memperkuat konsep siswa yang telah dibentuk terutama pada sub materi Hukum Archimedes. 


\section{DAFTAR RUJUKAN}

Anwari, I., Yamada, S., Unno, M., \& Saito, T. (2015). Implementation of Authentic Learning and Assessment Through STEM Education Approach to Improve Students ' Metacognitive Skills. K-12 STEM Education, 1(3), 123-124.

Berek, F. X., Sutopo, S., \& Munzil, M. (2016). Concept Enhancement of Junior High School Students in Hydrostatic Pressure and Archimedes Law by Predict-Observe-Explain Strategy. Jurnal Pendidikan IPA Indonesia, 5(2), 230-238. https://doi.org/10.15294/jpii.v5i2.6038

Brookes, D., \& Etkina, E. (2010). Physical Phenomena in Real Time. Science, 330(6004), 605-606. https://doi.org/10.1126/science.1186992

Buteler, L., \& Coleoni, E. (2016). Solving problems to learn concepts, how does it happen? A case for buoyancy. Physical Review Physics Education Research, 12(2), 1-12. https://doi.org/10.1103/PhysRevPhysEducRes.12.020144

Čančula, M. P., Planinšič, G., \& Etkina, E. (2015). Analyzing Patterns in Experts’ Approaches to Solving Experimental Problems. American Journal of Physics, 83(4), 366-374. https://doi.org/10.1119/1.4913528

Docktor, J. L., \& Mestre, J. P. (2014). Synthesis of Discipline-Based Education Research in Physics. Physical Review Physics Education Research, 20119, 1-58. https://doi.org/10.1103/PhysRevSTPER.10.020119

Docktor, J. L., Strand, N. E., Mestre, J. P., \& Ross, B. H. (2015). Conceptual Problem Solving in High School Physics. Physical Review Special Topics - Physics Education Research, 11(2), 1-13. https://doi.org/10.1103/PhysRevSTPER.11.020106

Donovan, M. S., \& Pellegrino, J. W. (2014). How People Learn : Bridging Research and Practice. Washington DC: National Academy Press.

Eraikhuemen, L., Ogumogu, A. E., Studies, C., \& State, E. (2014). An Assessment of Secondary School Physics Teachers Conceptual Understanding of Force and Motion in Edo. SAVAP International, 5(1), 253-262.

Ergin, S. (2016). The Effect of Group Work on Misconceptions of $9^{\text {th }}$ Grade Students about Newton's Laws. Journal of Education and Training Studies, 4(6), 127-136. https://doi.org/10.11114/jets.v4i6.1390

Goszewski, M., Moyer, A., Bazan, Z., \& Wagner, D. J. (2013). Exploring Student Difficulties with Pressure in a Fluid. AIP Conference Proceedings, 157(may 2012), 154-157. https://doi.org/10.1063/1.4789675

Hadzibegovic, Z., \& Klokic, M. (2016). Optical phenomena in the atmosphere: Questionnaire results of high school students' knowledge and understanding. AIP Conference Proceedings, 310003, 310003. https://doi.org/10.1063/1.4944313

Halim, L., Yong, T. K., Subahan, T., \& Meerah, M. (2014). Overcoming Students ' Misconceptions on Forces in Equilibrium : An Action Research Study, (June), 1032-1042.

Heron, P. R. L., Loverude, M. E., Shaffer, P. S., \& McDermott, L. C. (2003). Helping Students Develop an Understanding of Archimedes' Principle. II. Development of Research-Based Instructional Materials. American Journal of Physics, 71(11), 1188-1195. https://doi.org/10.1119/1.1607337

Herrington, A., \& Herrington, J. (2005). Authentic Learning Environments in Higher Education. (J. Neidig, Ed.). United States of America.

Hill, M., Sharma, M. D., \& Johnston, H. (2015). How Online Learning Modules Can Improve the Representational Fluency and Conceptual Understanding of University Physics Students. European Journal of Physics, 36(4), 45019. https://doi.org/10.1088/0143-0807/36/4/045019

Hubber, P., Tytler, R., \& Haslam, F. (2010). Teaching and Learning about Force with a Representational Focus : Pedagogy and Teacher Change, 5-28. https://doi.org/10.1007/s11165-009-9154-9

Hung, W., \& Jonassen, D. H. (2006). Conceptual Understanding of Causal Reasoning in Physics. International Journal of Science Education, 28(13), 1601-1621. https://doi.org/10.1080/09500690600560902

Kaur, G. (2017). Seeing Light. Contemporary Education Dialogue, 14(1), 22-48. https://doi.org/10.1177/0973184916678697

Kautz, C. H., Heron, P. R. L., Shaffer, P. S., Mcdermott, L. C., Kautz, C. H., Heron, P. R. L., ... Mcdermott, L. C. (2013). Student understanding of the ideal gas law, Part II : A Microscopic Perspective Student understanding of the Ideal Gas law , Part II : A microscopic perspective, 1064(2005). https://doi.org/10.1119/1.2060715

Leitï ${ }^{1} 120$, U. A., Dos Anjos Pinheiro Da Silva, A., Do Nascimento, N. C. T., \& Da Cruz Gervï ¿1/2sio, L. M. B. (2017). A bullet fired in dry water: An Investigative Activity to Learn Hydrodynamics Concepts. Physics Education, 52(1). https://doi.org/10.1088/1361-6552/52/1/015024

Loverude, M. E., Heron, P. R. L., \& Kautz, C. H. (2010). Identifying and Addressing Student Difficulties with Hydrostatic Pressure. American Journal of Physics, 78(2010), 75. https://doi.org/10.1119/1.3192767

Maina, F. (2015). Authentic Learning : Perspectives from Contemporary Educators. Journal of Authentic Learning, 1(1), 1-5.

Mims, C. (2003). Authentic Learning: A Practical Introduction \& Guide for Implementation. Meridian A Middle School Computer Technologies Journal, 6(1), 1-12.

Moodley, T. (2016). Authentic Learning for Teaching Reading : Foundation Phase Pre-Service Student Teachers' Learning Experiences of Creating and Using Digital Stories in Real Classrooms. Journal of the Reading Association of South Africa, $7(1), 1-10$.

Muganga, L. (2015). Authentic Learning in African Post-Secondary Education and the Creative Economy. Journal of University of Alberta, 7(2), 27-54. 
Nurita, T., Hastuti, P. W., \& Sari, D. A. P. (2017). Problem-Solving Ability of Science Students in Optical Wave Courses. Jurnal Pendidikan IPA Indonesia, 6(2), 341-345. https://doi.org/10.15294/jpii.v6i2.8184

Prain, V., Tytler, R., \& Peterson, S. (n.d.). About Evaporation Multiple Representation in Learning, (November 2014 ), $37-41$. https://doi.org/10.1080/09500690701824249

Riantoni, C., Yuliati, L., Mufti, N., \& Nehru, N. (2017). Problem Solving Approach in Electrical Energy and Power on Students as Physics Teacher Candidates. Jurnal Pendidikan IPA Indonesia, 6(1), 55-62. https://doi.org/10.15294/jpii.v6i1.8293

Robertson, A. D., Shaffer, P. S., Robertson, A. D., \& Shaffer, P. S. (2016). Pressure of an ideal gas University student reas oning about the basic tenets of kinetic-molecular theory, Part II : Pressure of an ideal gas. https://doi.org/10.1119/1.4960215

Rochmawati, Y., \& Wahyuni, S. (2017). Authentic Assessment in Physics Learning Using Physics Chess Game for Senior High School. International Journal of Learning and Teaching, 3(1), 15-18. https://doi.org/10.18178/ijlt.3.1.15-18

Rule, A. C. (2006). Editorial : The Components of Authentic Learning. Journal of Authentic Learning, 3(1), 1-10.

Sambeka, Y., \& Sriyati, S. (2017). Implementation of Authentic Assessment in The Project Based Learning to Improve Student' s Concept Mastering. AIP Conference Proceedings, 1-6. https://doi.org/10.1063/1.4983980

Sencar, S., \& Eryilmaz, A. (2004). Factors Mediating the Effect of Gender on Ninth-Grade Turkish Students' Misconceptions Concerning Electric Circuits, 41(6), 603-616. https://doi.org/10.1002/tea.20016

Serway, R. A., \& Vuille, C. (2014). Serway-Vuille College Physics (tenth). United States of America: Cengage Learning.

Stylos, G., Evangelakis, G. A., \& Kotsis, K. T. (2008). Misconceptions on Classical Mechanics by Freshman University Students: A Case Study in a Physics Department in Greece, 1(2), 157-177.

Teiermayer, A. (2016). Problems Based on Phenomena and Experiments in Secondary School Involving a Digital Camera. Physics Education, 51(6), 63002. https://doi.org/10.1088/0031-9120/51/6/063002

Wagner, D. J., Carbone, E., \& Lindow, A. (2013). Exploring Student Difficulties with Buoyancy. In American Association of Physics Teachers (pp. 357-360). https://doi.org/10.1119/perc.2013.pr.077

Wagner, D. J., Cohen, S., \& Moyer, A. (2009). Addressing Student Difficulties with Buoyancy. AIP Conference Proceedings, 1179, 289-292. https://doi.org/10.1063/1.3266739

Widowati, A., Nurohman, S., \& Anjarsari, P. (2017). Developing Science Learning Material with Authentic Inquiry Learning Approach to Improve Problem Solving and Scientific Attitude. Jurnal Pendidikan IPA Indonesia, 6(1), 32-40. https://doi.org/10.15294/jpii.v6i1.4851

Wijaya, C. P., Koes, S., \& Muhardjito. (2016). The Diagnosis of Senior High School Class X MIA B Students Misconceptions about Hydrostatic Pressure Concept Using Three-Tier. Jurnal Pendidikan IPA Indonesia, 5(1), 14-21. https://doi.org/10.15294/jpii.v5i1.5784

Yalcin, M., Altun, S., Turgut, U., \& Aggu, F. (2009). First Year Turkish Science Undergraduates' Understandings and Misconceptions of Light, 1083-1093. https://doi.org/10.1007/s11191-008-9157-3

Young, D. E., \& Meredith, D. C. (2017). Using the resources framework to Design, Assess, and Refine Interventions on Pressure in Fluids. Physical Review Physics Education Research, 13(1), 1-16. https://doi.org/10.1103/PhysRevPhysEducRes.13.010125 